\title{
THE INVESTIGATION OF USEABILITY OF NON-METRIC DIGITAL CAMERAS MOUNTED ON THE KITES PLATFORMS AT THE ARCHAEOLOGICAL DOCUMENTATION WORK
}

\author{
${ }^{1}$ Ali ULVI, ${ }^{2}$ Ahmet Suad TOPRAK, ${ }^{3}$ Murat YAKAR \\ ${ }^{1}$ Selcuk University, Hadim Vocational Schools of HigherEducation, Konya, Turkey \\ ${ }^{2}$ KOP Region of Development Administration, Konya, Turkey \\ ${ }^{3}$ Selcuk University, Faculty of Engineering, Department of Geomatic Engineering, 42075 Konya, Turkey \\ ${ }^{1}$ aliulvi@selcuk.edu.tr, ${ }^{2}$ ahmetsuadtoprak@gmail.com, ${ }^{3}$ yakar@selcuk.edu.tr
}

(Geliş/Received: 15.12.2016; Kabul/Accepted in Revised Form: 31.01.2017)

\begin{abstract}
In this study, obtaining of 3D model of theater and precision study was carried out on obtained model using kite photos of theater, at Uzuncaburc Diocaesarea of the ancient theater in the Province of Mersin Silifke District. As a result, using photogrammetric techniques with unmanned aircraft, it has been shown to provide adequate positioning accuracy archaeological documentation. In this way, the production base of the excavation, before and after excavations modeling, monitoring of the development period of the excavation, working area detection and it carries the base may be qualifications of the restoration project.
\end{abstract}

Key Words: Kite Photogrammetry, 3D model, Archaeological documentation

\section{Uçurtma Platformlarına Monte Edilen Metrik Olmayan Dijital Kameraların Arkeolojik Dökümantasyon Çalışmalarında Kullanılabilirliğinin Araştırılması}

ÖZ: Bu çalışmada, Mersin Silifke İlçesi'ndeki antik tiyatronun Uzuncaburc Diocaesarea'sında, tiyatronun uçurtma fotoğraflarını kullanarak tiyatronun $3 \mathrm{~B}$ modelinin elde edilmesi ve hassasiyet araştırması yapılmıştır. Sonuç olarak, insansız uçaklarla fotogrametrik teknikler kullanılarak, yeterli aralıklarla arkeolojik belgeler belirlenmesi sağlanmıştır. Bu şekilde, kazının üretim üssü, kazı modellemesi öncesi ve sonrası, kazı gelişim döneminin izlenmesi, çalışma alanı tespiti ve temel taşıdığı restorasyon projesinin nitelikleri olabilir.

Key Words: Uçurtma Fotogrametrisi, 3B model, Arkeolojik Dökümantasyon

\section{INTRODUCTION}

Kites have been utilized for lifting photographic cameras since the late 19th century (Beauffort and Dusariez, 1995). KAP became popular in the early years of the 20th century, in fact, before being replaced by photographs from airplanes in the 1920s and 1930s. For the next several decades, KAP was virtually a lost art (Hart, 1982).

Terrestrial photogrammetry technique is a method Which was used for archeological measurements and Documentation of historical artifacts for ages. Photogrammetry, along with the development of digital Techniques, became a more efficient and economical method documentation and protection of architectural works. Recently, as a result of improvements on 
digital photogrammetry and computer technology, reconstruc-Tution of buildings as threedimensional took part amongst Current research topics. Day by day modelling a building As threedimensional has almost become obliga-tory for Tourism and urban planning (Suveg and Vosselman, 2000). As well known, aerial images are most suitable Database for evaluating and mapping objects. But the High-cost of aircraft campaigns force the scientists and Photogrametrists to think about cheaper solutions Especially for smaller areas. These solutions are (Leloglu et al., 2003; Ulvi and Yakar, 2010):

- Kite.

- Balloon.

- Remote controlled model helicopter.

- Remote controlled model aircraft.

In some regions on the world, kites have been used for aerial photos in scientific researches. Kite aerial photography has been utilized for various types of scientific survey and mapping projects. Bigras (1997) used KAP to produce stereo imagery of a fossil forest bed on Axel Heiberg Island, Arctic Canada. De-tailed mapping of fossil tree stumps was carried out in order to monitor erosion and assess visitor impact at the site. Behavior of penguins in Ant-arctica was documented with KAP by Carlson (1997) could be photographed. KAP was the basis for geologic and archeologic mapping in connection with the wintering site of Dutch Explorer Willem Barents in 1596-97 on Novaya Zemlya, Arctic Russia (Bults, 1997). Warner (1996) has coined the term kiteography, which is the use of KAP in making large- scale topographic maps, based on photogrammetric principles. Overlap-ping, stereo-pairs of photographs are processed digitally to create maps and 3-dimensional displays of the ground.

Research is focused on the use of non-conventional aerial platforms developed for aerial photogrammetric surveys. Different tests have been performed using various platforms, (Everaerts, 2008; Eisenbeiss, 2009; F. Chiabrando et. al., 2011) such as helium balloons (Altan et al., 2004; Celikoyan et al., 2003; Fotinopoulos, 2004; Gesafidis et al., 1999), kites (Aber et al., 2002; Bitelli et al., 2003; Bogacki et al., 2008), fixed-wing platforms (Bendea et al., 2007).

Smith et al. (2009) used a kite platform as it remains comparatively inexpensive, is extremely portable and can operate in a variety of environments (Figure 1-2).

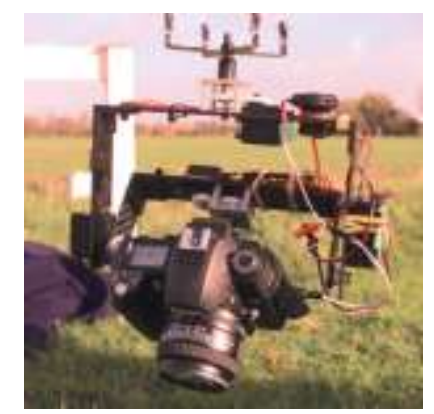

Figure 1. Remote controlled rig and camera used for the acquisition of aerial imagery (Smith et al., 2009).

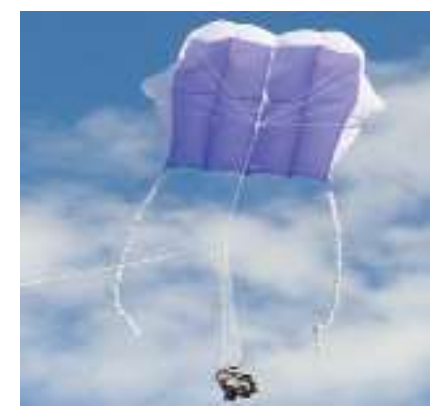

Figure 2. Unframed (parafoil) kite used for lifting the rig and camera payload (Smith et al., 2009). 


\section{STUDY AREA}

This study was carried out in Silifke town Mersin province Uzuncaburc Diocaesarea ancient theater in (Figure 3). Olba has been an ancient city of Cilicia. It was located about 25 kilometers northeast from Silifke. In the 1st century the nearby sanctuary of Zeus Olbius evolved into a separate city under the name Diocaesareia. The location of the sanctuary and the new city has been identified with the modern village of Uzuncaburc, at a distance of 4 kilometres from Olba (URL1).

For the first time, It has been shown the placement at Hellenistic period, Roman and Late antiquity periods, lived its best intense of, and had its most brilliant period in the 4th century AD. Finally, the Byzantine emperor II. Theodosius I, a Christian holy center set up here.

Different practices are used in the documentation work of archaeological sites. These are terrestrial laser scanning, terrestrial photogrammetry, HR hotogrammetry and Kite photogrammetry. Kite photogrammetry was preferred because of the intense wind in the study area.

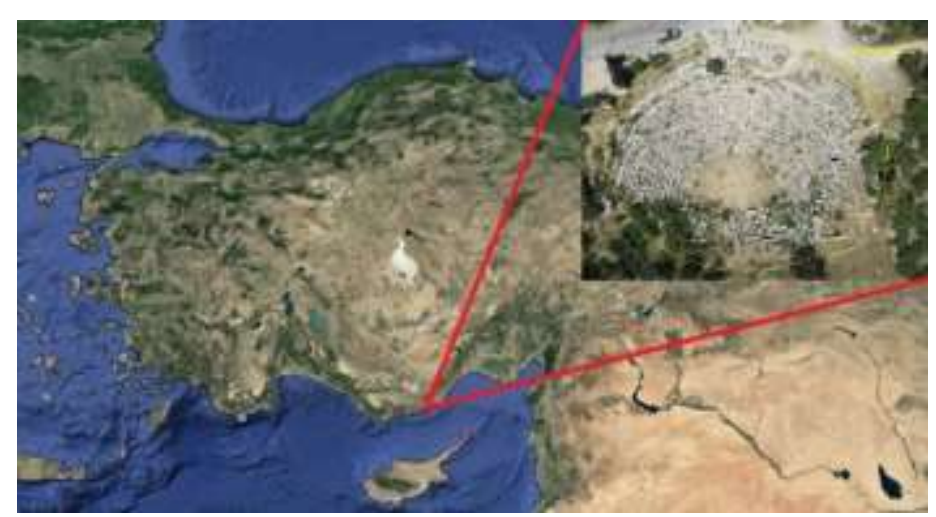

Figure 3. General view of Uzuncaburc theatre

\section{MATERIAL METHOD}

\section{Pre-work preparation}

In this study, Kite (Figure 4), digital camera and platform (Figure 5-6), a total station (Figure 7) and location the control plates to use for evaluation of the photographs from the obtained UAV has been supplying (Figure 8).

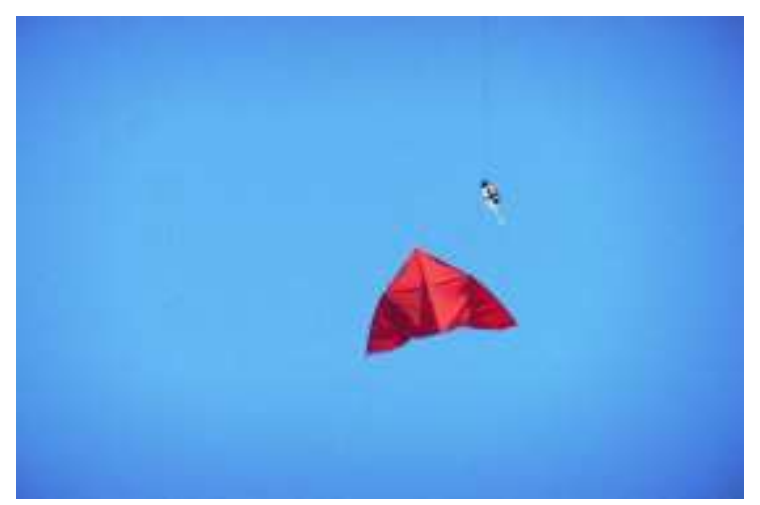

Figure 4.Delta Kite

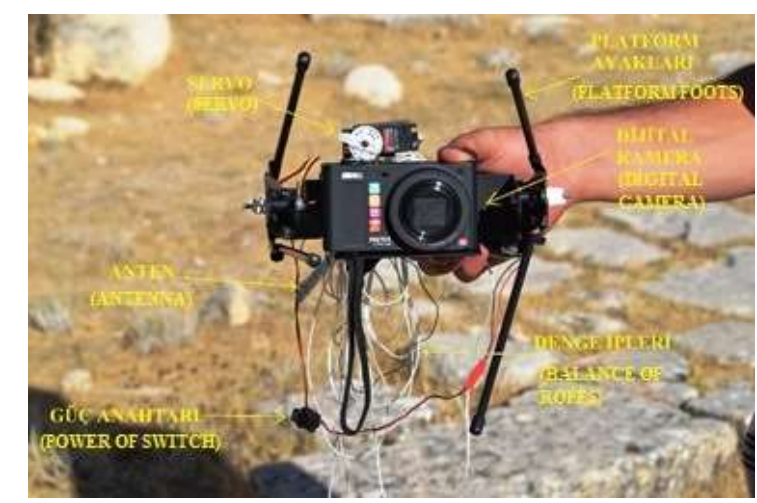

Figure 5. Digital Camera and carrier platform 


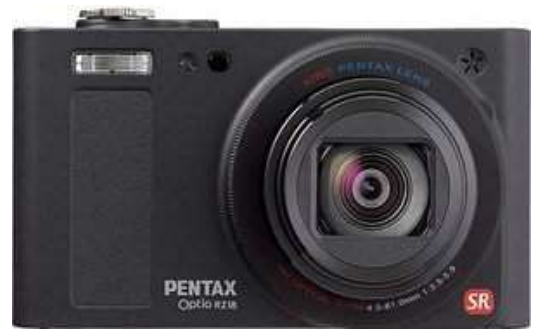

\begin{tabular}{|c|c|}
\hline \multicolumn{2}{|c|}{ PENTAX RZ18 Technicial Specifications } \\
\hline Effective & \\
\hline Megapixel & $16 \mathrm{Mp}$ \\
\hline Sensor Size & 1/2.33"(6.08x4.56mm) \\
\hline Resolution & $4608 \times 3456$ \\
\hline Pixel Size & $1.32 \mu \mathrm{m}$ \\
\hline Focal Length & 4.8421 \\
\hline
\end{tabular}

Figure 6.Pentax RZ18 Technicial Specifications

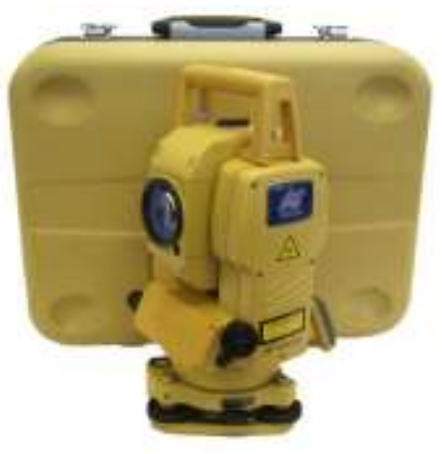

\begin{tabular}{|c|c|}
\hline \multicolumn{2}{|c|}{ DISTANCE MEASUREMENT } \\
\hline \multicolumn{2}{|l|}{ Measurug Rauge } \\
\hline Non grasm Mode & (Target: Kodak Whate) \\
\hline \begin{tabular}{|l|} 
In low laght condation and \\
withont sun glare on targer
\end{tabular} & 1.5 to $250 \mathrm{ma}(5$ to $820 \mathrm{ft})$ \\
\hline \multicolumn{2}{|l|}{ Prism Mode } \\
\hline $\begin{array}{l}\text { Condition } 1^{*} \\
(1 \text { prism) }\end{array}$ & $3,000 \mathrm{~m}(9,900 \mathrm{ft})$ \\
\hline \multicolumn{2}{|l|}{ Mensurement Accuracy } \\
\hline Non-prism Mode & (Diffusing Stuface) \\
\hline $1.5902 .5 \mathrm{~m}(5$ to $82 \mathrm{ft})$. & $\neq(10 \mathrm{~mm}) \mathrm{m}$. s.e. \\
\hline $\begin{array}{l}25 \mathrm{~m} \text { or more }(82 \mathrm{ft} \text { of } \\
\text { mote) }\end{array}$ & $=(5 \mathrm{~mm}) \mathrm{au} . \mathrm{s} . \mathrm{e}$. \\
\hline Prism Mode & $\begin{array}{c}=(3 \mathrm{~mm}+2 p p m \times \text { D }) \text { mi s.e. D Measuring dastance } \\
(\text { (mun) }\end{array}$ \\
\hline
\end{tabular}

Figure 7.Topcon GPT - 3007 Reflektorless Total Station and Technicial Specifications

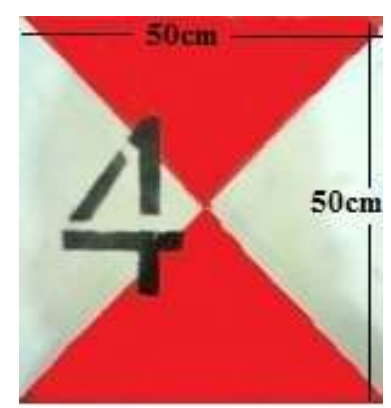

Figure 8. Ground control point target

\section{Field Study}

Ground Control Points was placed homogeneously and completely to cover study area of theatre in the field (Figure 9). The number of GCP is used a total of 30. Of these, 20 of them in the precision study, and 10 of them were used in the work of adjustment of the pictures. 


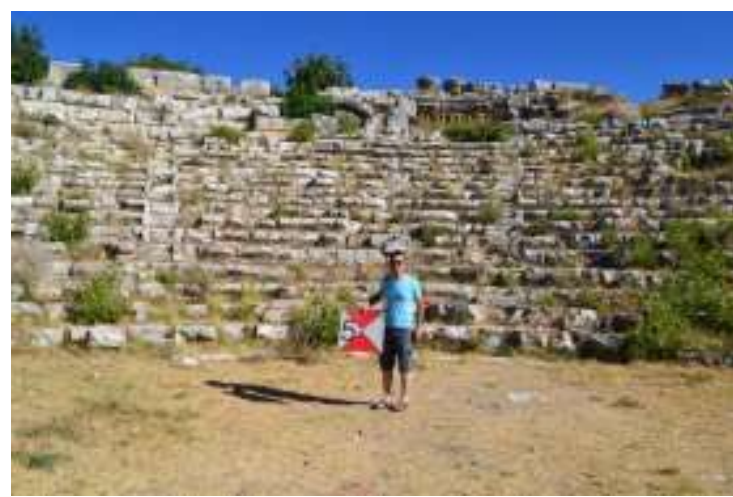

Figure 9. Placing of GCP

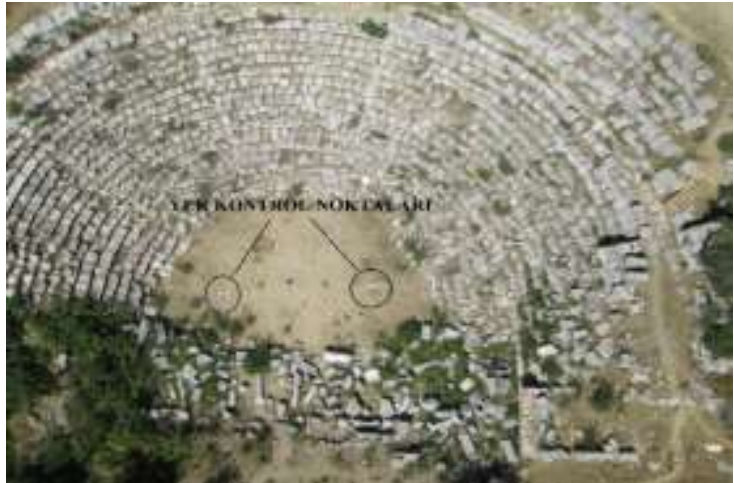

Figure 10. General view of GCP from air

After finishing the establishment of GCP point, measurements were made with total station and GCP point coordinates are calculated. GCP georeferencing process is made with Topcon GPT 3007 reflectorless total station. Within the application field, two traverse net established and GCP coordinates are calculated. GCP coordinates were evaluated in the Local Coordinate System.

After the georeferencing process, digital camera and kite carrier platform is mounted (Figure 12).After kite for final controls, kite flying operation performed, the photographing operation theater work has been completed (Figure 13). It was noted that the camera platform does not swing and the entire area of the photos can be seen when taking pictures. Photos have been taken from a height of approximately 25 $\mathrm{m}-30 \mathrm{~m}$.

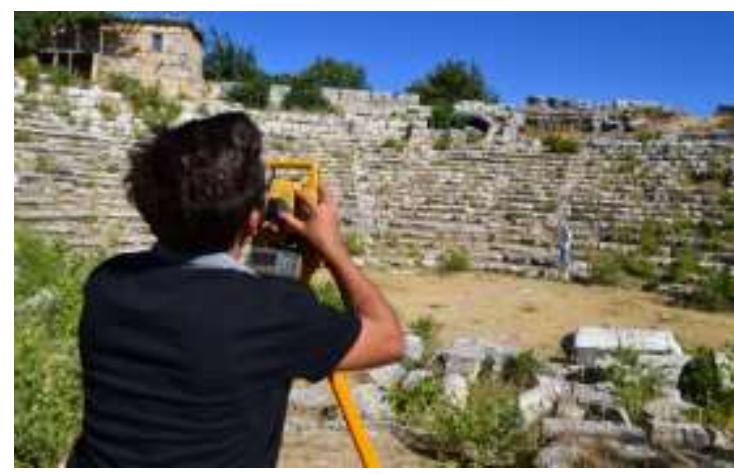

Figure 11. GCP measurement

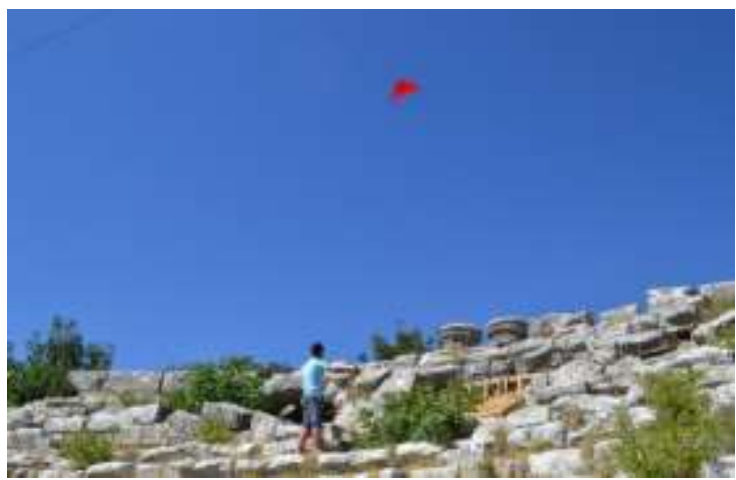

Figure 13. Taking photos from kite

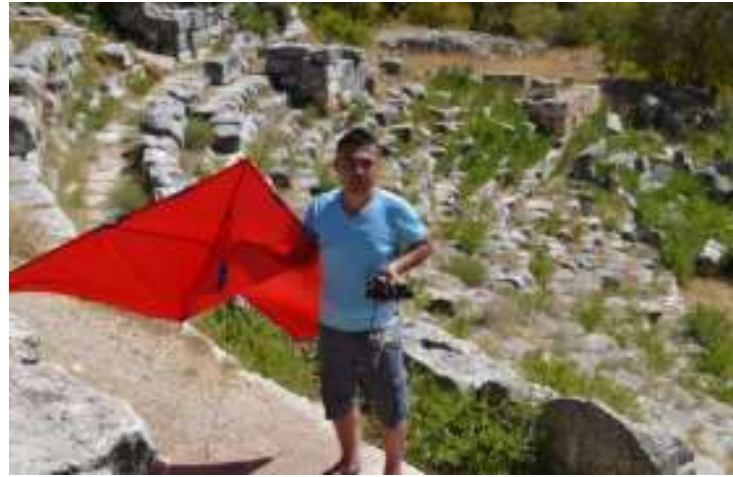

Figure 12. Mounting of camera to kite platform

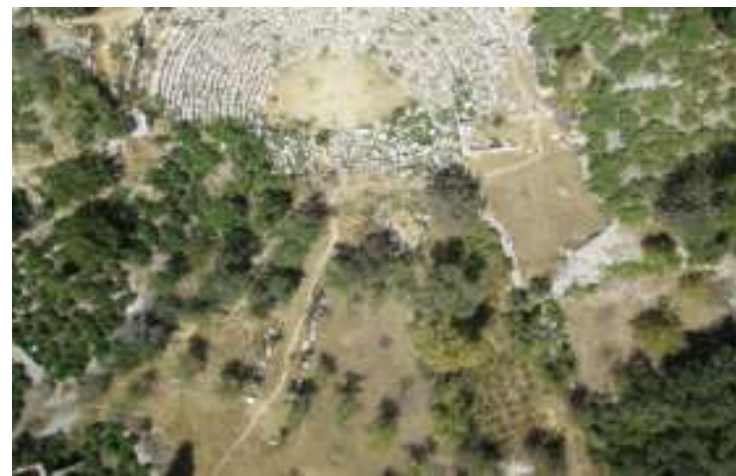

Figure 14. Taken photo sample from the air by kite

\section{Office work}

Before the evaluation process, the calibration values of the digital camera used were introduced to the Photomodeler software. About 50 photos have been taken from kite. By selecting the appropriate 
ones among these photographs, 9 photographs have been automatically adjusted in Photomodeler software. When balancing is done, it is taken care that the residual value is 5 denier. The residual value obtained for this study is 2.10 .

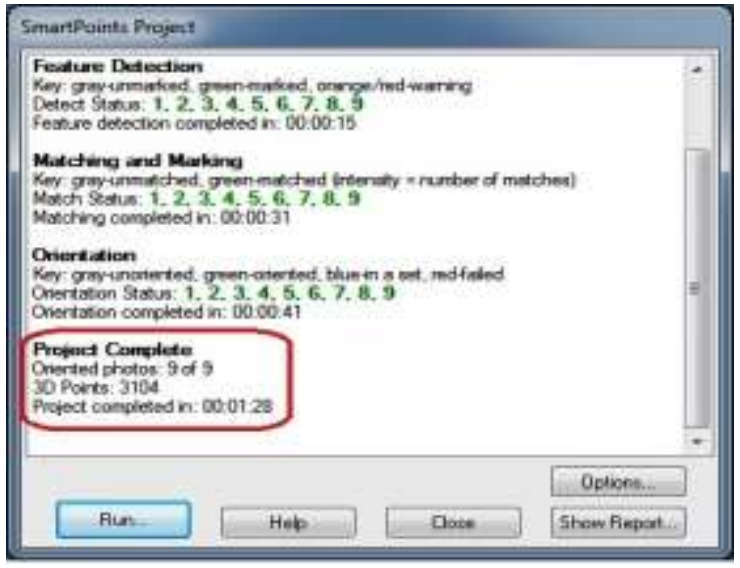

Figure 16. automatically adjustment of 9 photos

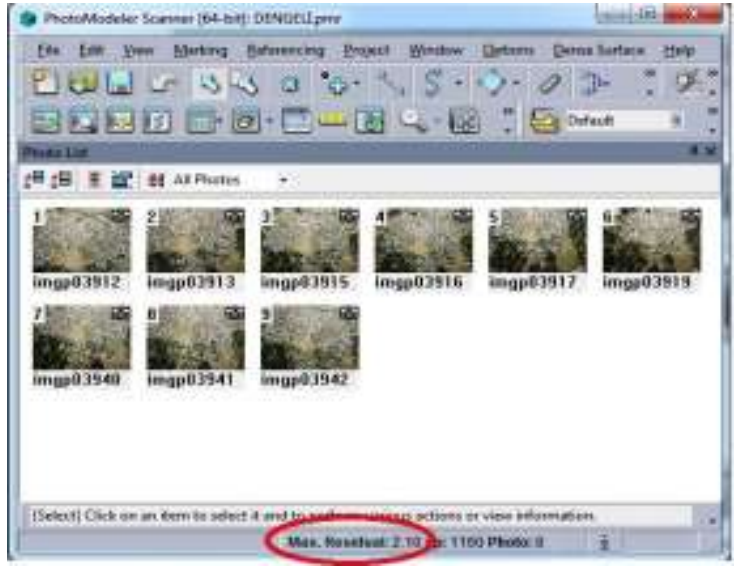

Figure 17. Adjusted photos at Photomodeler software

in Photomodeler software

After these procedures, Ground Control Points are referenced on different photos in Photomodeler software (Figure 19).

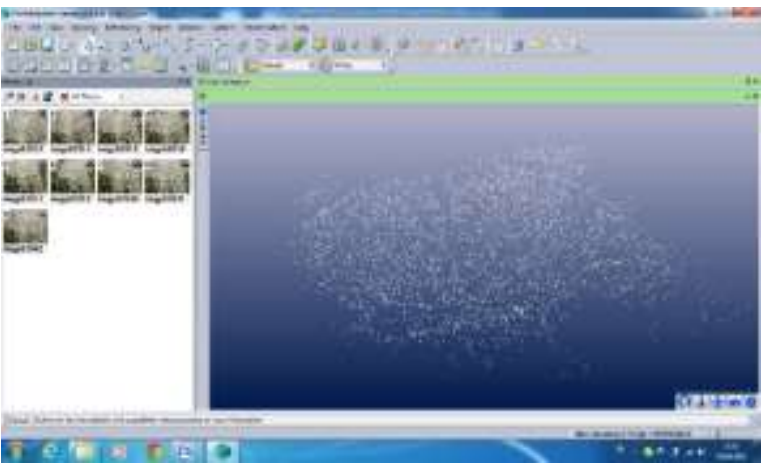

Figure 18. Referance points that ontained automaticallly in Photomodeler software

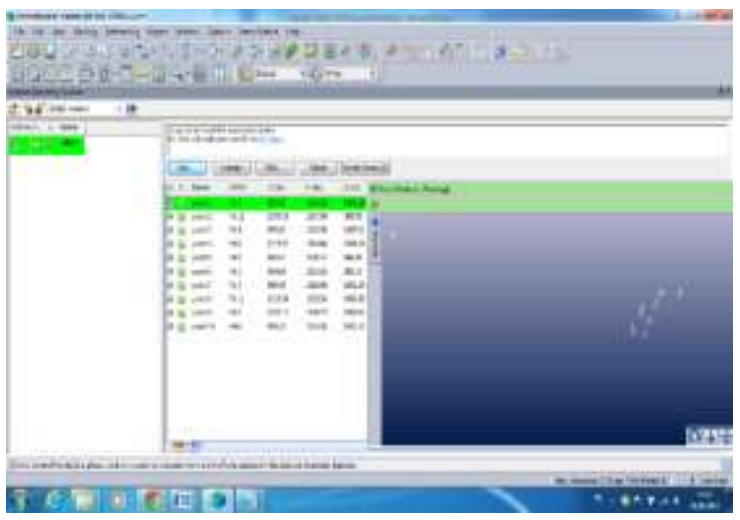

Figure 20. Georeferencing of referencing points by the Ground control points

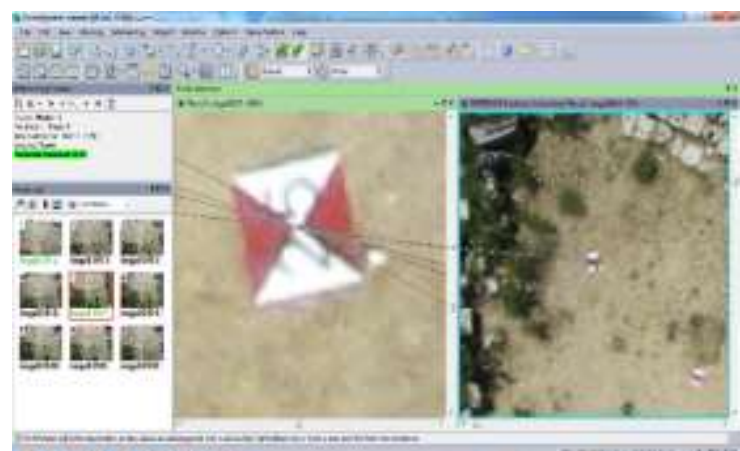

Cic

Figure 19. Referencing of ground control points at different photographs at Photomodeler software

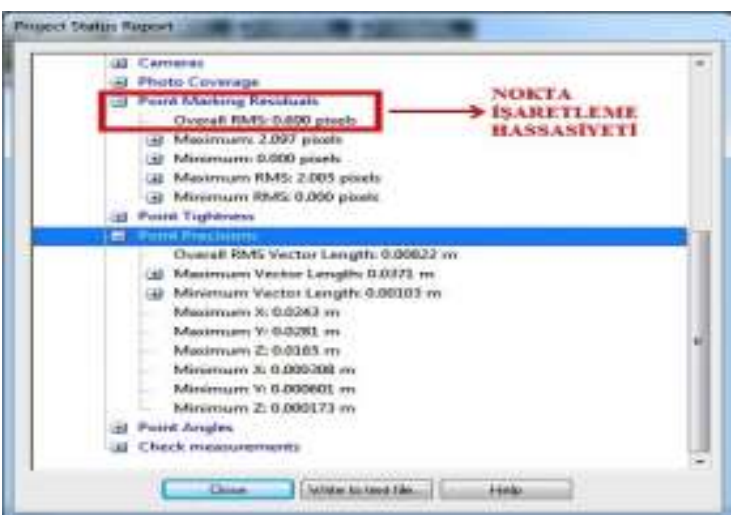

Figure 21. Adjustment report 


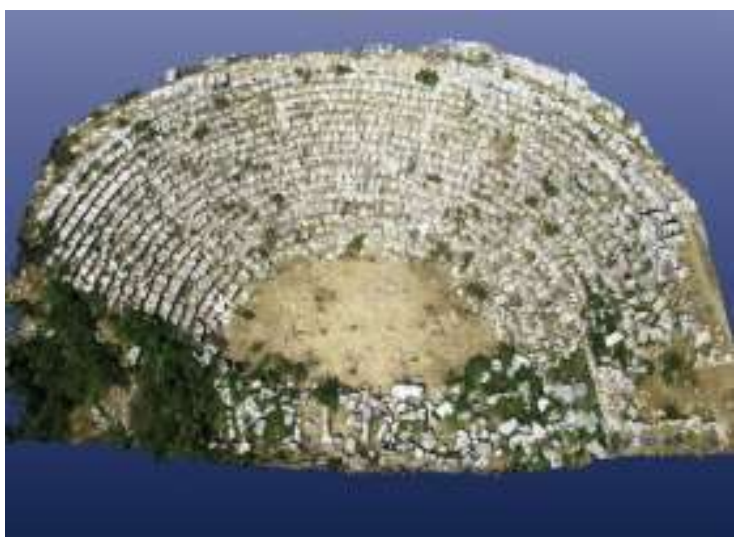

Figure 22. Textured model of point clouds at

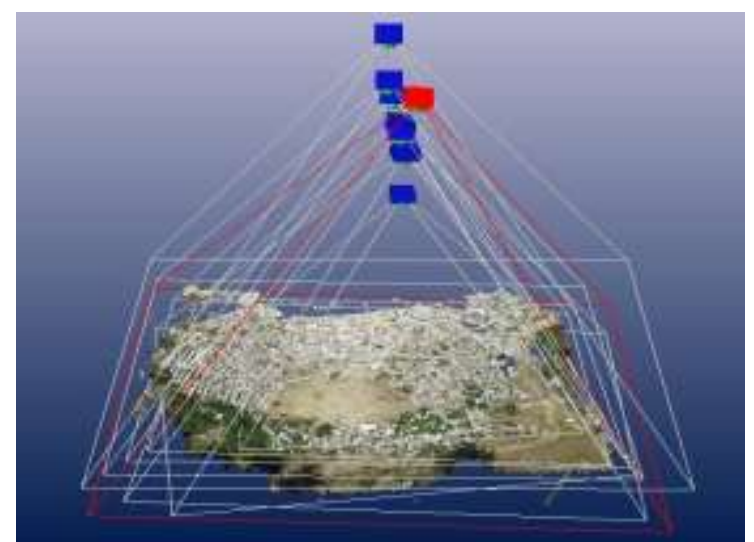

Figure 23. The position of photograps

PhotoModeler software

After this phase, the UAV kite, photogrammetric techniques of using the archaeological documentation of the application, precision survey was conducted. For this study, 30 ground control points are used in the established area of the application, (Figure 24)

Ground control points, coordinates, measured in the survey with total station and accuracy of the device is considered to be absolute coordinates (Figure 24).

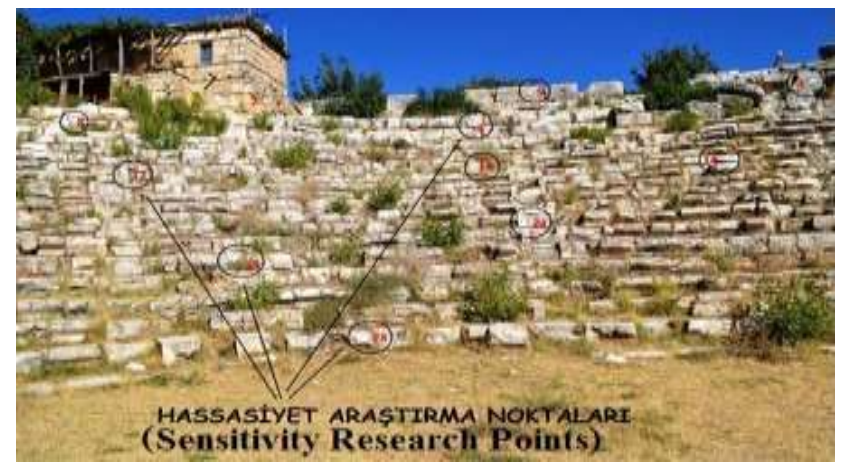

Figure 24. The distribution of points for the sensitivity study

After this process, ground control points of the coordinate value on the archaeological documentation, is calculated. 
Table 1. Coordinate values of GCP

\begin{tabular}{|l|c|c|c|c|c|c|}
\hline \multicolumn{3}{|c|}{ REAL COORDINATES } & \multicolumn{3}{c|}{ MODELLING } \\
\hline C.N. & Y & X & Z & Y & X & Z \\
\hline K 1 & 1023.634 & 1009.552 & 1006.522 & 1023.672 & 1009.516 & 1006.495 \\
\hline K 2 & 1020.703 & 1021.16 & 1006.421 & 1020.671 & 1021.118 & 1006.388 \\
\hline K 3 & 1012.97 & 1030.519 & 1006.245 & 1012.996 & 1030.556 & 1006.273 \\
\hline K 4 & 1002.242 & 1036.682 & 1007.7 & 1002.229 & 1036.646 & 1007.668 \\
\hline K 5 & 991.483 & 1039.093 & 1009.702 & 991.463 & 1039.067 & 1009.666 \\
\hline K 6 & 990.783 & 1033.13 & 1006.7 & 990.816 & 1033.102 & 1006.662 \\
\hline K 7 & 982.624 & 1031.839 & 1008.76 & 982.643 & 1031.808 & 1008.725 \\
\hline K 8 & 980.398 & 1024.528 & 1006.401 & 980.417 & 1024.512 & 1006.382 \\
\hline K 9 & 977.241 & 1018.002 & 1006.346 & 977.268 & 1017.971 & 1006.318 \\
\hline K 10 & 978.65 & 1011.404 & 1006.38 & 978.675 & 1011.437 & 1006.359 \\
\hline K 11 & 982.33 & 1013.645 & 1003.387 & 982.362 & 1013.614 & 1003.426 \\
\hline K 12 & 985.527 & 1022.363 & 1003.531 & 985.556 & 1022.346 & 1003.549 \\
\hline K 13 & 992.379 & 1028.683 & 1003.89 & 992.416 & 1028.719 & 1003.923 \\
\hline K 14 & 999.083 & 1028.871 & 1003.332 & 999.117 & 1028.906 & 1003.368 \\
\hline K 15 & 1005.509 & 1030.278 & 1004.553 & 1005.545 & 1030.247 & 1004.574 \\
\hline K 16 & 1008.329 & 1026.51 & 1003.259 & 1008.287 & 1026.473 & 1003.227 \\
\hline K 17 & 1016.628 & 1022.187 & 1005.248 & 1016.675 & 1022.158 & 1005.221 \\
\hline K 18 & 1018.01 & 1016.236 & 1004.992 & 1018.031 & 1016.206 & 1005.024 \\
\hline K 20 & 1014.097 & 1007.15 & 1003.087 & 1014.135 & 1007.191 & 1003.121 \\
\hline K 21 & 1011.266 & 1019.187 & 1001.485 & 1011.295 & 1019.227 & 1001.448 \\
\hline K 22 & 1005.204 & 1023.528 & 1001.142 & 1005.184 & 1023.502 & 1001.116 \\
\hline K 23 & 1000.888 & 1023.945 & 1000.903 & 1000.932 & 1023.917 & 1000.88 \\
\hline K 24 & 994.863 & 1024.487 & 1001.483 & 994.881 & 1024.458 & 1001.458 \\
\hline K 25 & 990.887 & 1020.15 & 1000.751 & 990.906 & 1020.134 & 1000.732 \\
\hline K 26 & 985.783 & 1014.191 & 1001.874 & 985.823 & 1014.157 & 1001.846 \\
\hline K 27 & 989.711 & 1014.716 & 999.622 & 989.736 & 1014.749 & 999.59 \\
\hline K 28 & 993.844 & 1019.475 & 999.205 & 993.884 & 1019.439 & 999.232 \\
\hline K 29 & 1001.635 & 1020.809 & 999.258 & 1001.674 & 1020.792 & 999.276 \\
\hline K 31 & 1012.801 & 1012.943 & 1001.111 & 1012.834 & 1012.979 & 1001.144 \\
\hline
\end{tabular}

Table 2. Coordinate differences and root mean square error of ground control points

\begin{tabular}{|c|c|c|c|c|c|c|c|c|}
\hline \multicolumn{3}{|c|}{ DIFFERENCES(m) } & \multicolumn{3}{|c|}{$\begin{array}{c}\text { Vi } \\
\text { DIFFERENCES(cm) }\end{array}$} & \multicolumn{3}{|c|}{\begin{tabular}{|c|} 
ViVi \\
DIFFERENCES(cm) \\
\end{tabular}} \\
\hline $\mathbf{Y}$ & $\mathbf{X}$ & $\mathbf{Z}$ & $\mathbf{Y}$ & $\mathbf{x}$ & $\mathbf{Z}$ & $\mathbf{Y}$ & $\mathbf{x}$ & $\mathbf{Z}$ \\
\hline 0.038 & -0.04 & -0.027 & 3.8 & -3.6 & -2.7 & 14.4 & 13 & 7.3 \\
\hline-0.032 & -0.04 & -0.033 & -3.2 & -4.2 & -3.3 & 10.2 & 17.6 & 10.9 \\
\hline 0.026 & 0.037 & 0.028 & 2.6 & 3.7 & 2.8 & 6.8 & 13.7 & 7.8 \\
\hline-0.013 & -0.04 & -0.032 & -1.3 & -3.6 & -3.2 & 1.7 & 13 & 10.2 \\
\hline-0.02 & -0.03 & -0.036 & -2 & -2.6 & -3.6 & 4 & 6.8 & 13 \\
\hline 0.033 & -0.03 & -0.038 & 3.3 & -2.8 & -3.8 & 10.9 & 7.8 & 14.4 \\
\hline 0.019 & -0.03 & -0.035 & 1.9 & -3.1 & -3.5 & 3.6 & 9.6 & 12.3 \\
\hline 0.019 & -0.02 & -0.019 & 1.9 & -1.6 & -1.9 & 3.6 & 2.6 & 3.6 \\
\hline 0.027 & -0.03 & -0.028 & 2.7 & -3.1 & -2.8 & 7.3 & 9.6 & 7.8 \\
\hline 0.025 & 0.033 & -0.021 & 2.5 & 3.3 & -2.1 & 6.3 & 10.9 & 4.4 \\
\hline 0.032 & -0.03 & 0.039 & 3.2 & -3.1 & 3.9 & 10.2 & 9.6 & 15.2 \\
\hline 0.029 & -0.02 & 0.018 & 2.9 & -1.7 & 1.8 & 8.4 & 2.9 & 3.2 \\
\hline 0.037 & 0.036 & 0.033 & 3.7 & 3.6 & 3.3 & 13.7 & 13 & 10.9 \\
\hline 0.034 & 0.035 & 0.036 & 3.4 & 3.5 & 3.6 & 11.6 & 12.3 & 13 \\
\hline 0.036 & -0.03 & 0.021 & 3.6 & -3.1 & 2.1 & 13 & 9.6 & 4.4 \\
\hline-0.042 & -0.04 & -0.032 & -4.2 & -3.7 & -3.2 & 17.6 & 13.7 & 10.2 \\
\hline 0.047 & -0.03 & -0.027 & 4.7 & -2.9 & -2.7 & 22.1 & 8.4 & 7.3 \\
\hline 0.021 & -0.03 & 0.032 & 2.1 & -3 & 3.2 & 4.4 & 9 & 10.2 \\
\hline 0.038 & 0.041 & 0.034 & 3.8 & 4.1 & 3.4 & 14.4 & 16.8 & 11.6 \\
\hline 0.029 & 0.04 & -0.037 & 2.9 & 4 & -3.7 & 8.4 & 16 & 13.7 \\
\hline-0.02 & -0.03 & -0.026 & -2 & -2.6 & -2.6 & 4 & 6.8 & 6.8 \\
\hline 0.044 & -0.03 & -0.023 & 4.4 & -2.8 & -2.3 & 19.4 & 7.8 & 5.3 \\
\hline 0.018 & -0.03 & -0.025 & 1.8 & -2.9 & -2.5 & 3.2 & 8.4 & 6.3 \\
\hline 0.019 & -0.02 & -0.019 & 1.9 & -1.6 & -1.9 & 3.6 & 2.6 & 3.6 \\
\hline 0.04 & -0.03 & -0.028 & 4 & -3.4 & -2.8 & 16 & 11.6 & 7.8 \\
\hline 0.025 & 0.033 & -0.032 & 2.5 & 3.3 & -3.2 & 6.3 & 10.9 & 10.2 \\
\hline 0.04 & -0.04 & 0.027 & 4 & -3.6 & 2.7 & 16 & 13 & 7.3 \\
\hline 0.039 & -0.02 & 0.018 & 3.9 & -1.7 & 1.8 & 15.2 & 2.9 & 3.2 \\
\hline \multirow[t]{3}{*}{0.033} & 0.036 & 0.033 & 3.3 & 3.6 & 3.3 & 10.9 & 13 & 10.9 \\
\hline & & & & \multicolumn{2}{|c|}{$[\mathrm{VV}]$} & 287.2 & 293 & 252.9 \\
\hline & & & & \multicolumn{2}{|c|}{$w= \pm \sqrt{\frac{i n \cdot n]}{n}}$} & 3.1 & 3.1 & 2.9 \\
\hline
\end{tabular}

Table 3. Archaeological documentation precision research results produced using a kite with UAV photogrammetric techniques.

\begin{tabular}{|c|ccc|}
\cline { 2 - 4 } \multicolumn{1}{c|}{} & $\mathrm{Vy}(\mathrm{cm})$ & $\mathrm{Vx}(\mathrm{cm})$ & $\mathrm{Vz}(\mathrm{cm})$ \\
\hline $\mathrm{m}$ & \pm 3.1 & \pm 3.1 & \pm 2.9 \\
$\mathrm{~m}_{\mathrm{yxz}}$ & & \pm 5.3 & \\
\hline
\end{tabular}

As a result of this data, using photogrammetric techniques with UAV kite, precision research of the produced archaeological documentation data, $\mathrm{y}, \mathrm{x}$ and $\mathrm{z}$ coordinates were found in the average position error is $\pm 5.3 \mathrm{~cm}$ (Table 3 ). 


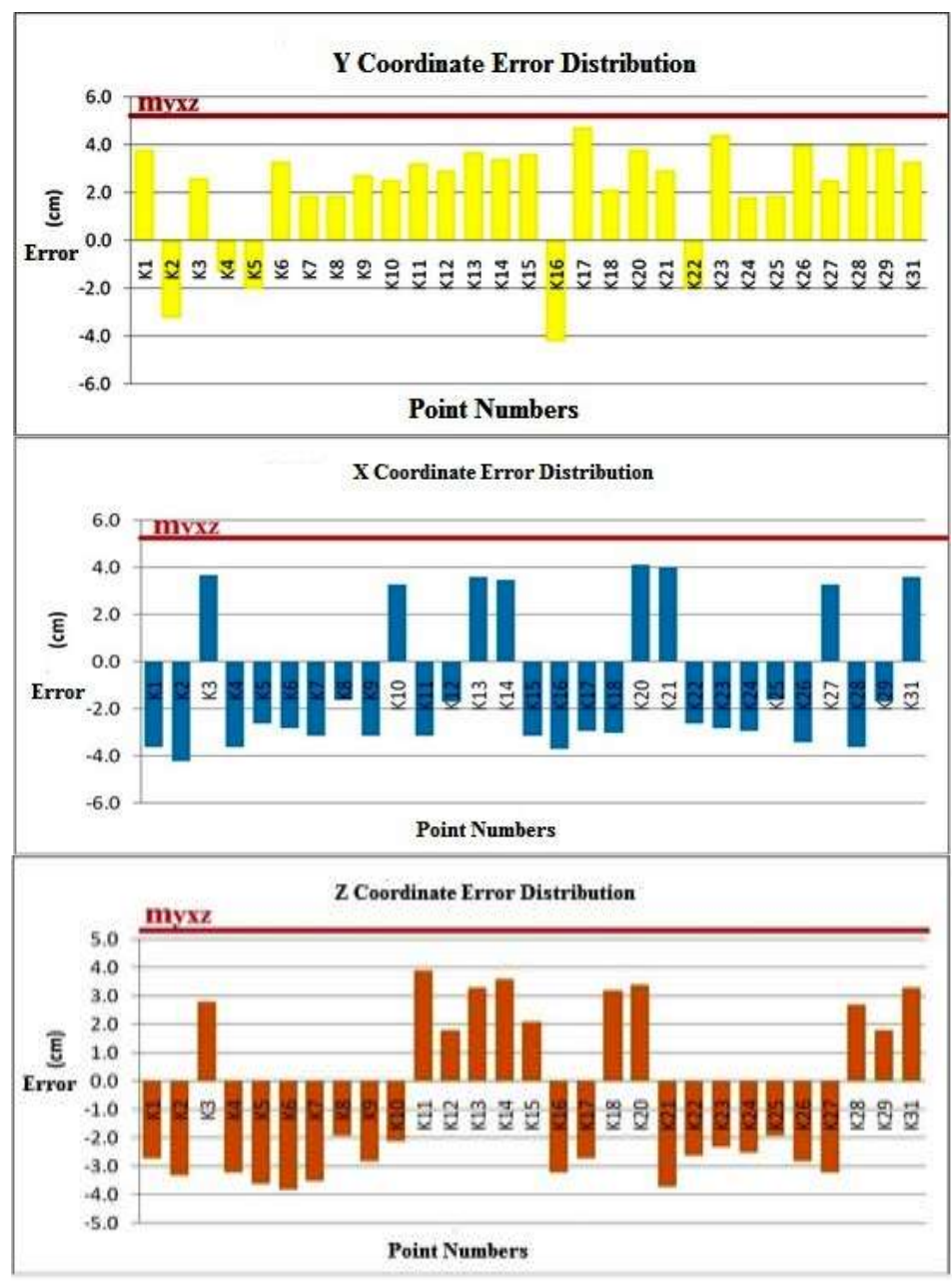

Figure 25. The position error distribution of ground control points, at $\mathrm{xy}$ and $\mathrm{z}$ axis

\section{COMPARASION OF KITE PHOTOGRAMMETRY WITH TERRESTRIAL LASEL SCANNING AND TERRESTRIAL PHOTOGRAMMETRY}

Terrestrial laser scanning (TLS), terrestrial photogrammetry and kite photogrammetry have advantages and disadvantages when compared to each other.Terrestrial laser scanning is a technology which can take essential points to create high-resolution 3D model in a short time.

This system can automatically obtain the 3D coordinates of the work area in the complex structure. Although terrestrial laser scanning technology has some disadvantages, it has significant advantages. These advantages can be listed as the acquisition of 3D points directly, very effective in identifying of irregularly structured objects, obtaining of the result in a short time.The main disadvantages are distance limitation, high image cost, and inability to obtain object-oriented features (Demir et al., 2004).

Terrestrial photogrammetry is a method that has been used for many years to document archaeological measurements and historical monuments. The 3D models of the works provide considerable convenience. The disadvantage of high-rise buildings is that they can not be photographed by traditional methods. Kite photogrammetry can display all the details of the objects in a short time. The price is affordable. It's easy to use. It is one of the alternative documentation techniques. The disadvantage is that it can not be used in windless weather. 


\section{RESULTS}

Kite aerial photography is a low-cost means to acquire largescale,high-resolution, multi-view angle images for diverse applications. KAP applications span the range of scientific and commercial possibilities including: archaeology, architecture, forestry, geomorphology,golf-course management, property survey, and wetland study (James S. Aber and Susan W. Aber,2002)

Determination of the current situation of the historical heritages, brings great convenience in terms of time and accuracy for the protection studies, architectural survey projects, Research has shown that the work can be digitized, the resulting product is more rich visual information, and the data obtained makes it possible to be always updated and shared.

In this study, according to the calculated results, using photogrammetric techniques with UAVs, providing sufficient positioning accuracy of archaeological documentation. In this way, the production base of the excavation work, both before and after excavation, modeling, monitoring the development of the excavation period, the working area detection and restoration projects move necessary conditions to become basic.

In terms of time and cost concept, archeological documentation that provides a great advantage over the 3D model of the desired size and value can be obtained precisely.

Moreover, by export to different data format from Photomodeler software, other software used according to the intended purpose.

\section{ACKNOWLEDGMENT}

This study was prepared for Ali ULVI's Doctorate thesis.

\section{REFERENCES}

Aber, J.S., Aber, S.W., Pavri, F., 2002, "Unmanned Small-format Aerial Photography from Kites for Acquiring Large Scale, High-resolution, Multiview-angle Imagery", ISPRS Archives, Pecora 15/Land Satellite Information IV/ISPRS Commission I/FIEOS, Denver, CO, USA.

Altan, M.O., Celikoyan, T.M., Kemper, G., Toz, G., 2004,"Balloon Photogrammetry for Cultural Heritage", In: ISPRS Archives Vol. XXXV-B5, XX ISPRS Congress, Istanbul, Turkey, pp. $964 \mathrm{e} 968$.

Beauffort, G.de, Dusariez, M., 1995, Aerial Photographs Taken from a Kite: Yesterday and Today. KAPWA-Foundation Pub.

Bendea, H., Chiabrando, F., Tonolo, F.G., Marenchino, D., 2007," Mapping of Archaeological Areas Using a Low-cost UAV", The Augusta Bagiennorum Test Site.In: ISPRS Archives Vol. XXXVI5/W1, pp. 117e122.

Bigras, C., 1997, "Kite Aerial Photography of The Axel Heiberg Island Fossil Forest", Am. Soc. Photogrammetry and Remote Sensing", The First North American Symposium on Small Format Aerial Photography: Technical Papers, pp. 147-153

Bitelli, G., Tini, M.A., Vittuari, L., 2003, "Low-height Aerial Photogrammetry for Archaeological Orthoimaging Production", International Archives Of Photogrammetry Remote Sensing And Spatial Information Sciences In: ISPRS Archives Vol. XXXIV, Part 5/W12, pp. 55e-59.

Bogacki, M., Malkowski, W., Misiewicz, K., 2008, "Kite Aerial Photography (KAP) as a Tool for Completing GIS Models. Ptolemais (Libya) Case Study", In: Lasaponara, R., Masini, N., Aracne (Eds.), Remote Sensing for Archaeology and Cultural Heritage Management. Proceedings of the 1st International EARSeL Workshop, CNR, Roma, pp. 329e332.

Bults, P., 1997,"Northeast to Cathay" The Aerial Eye 3.2:10-11. 
Carlson, J., 1997, "Kite Flying in The Freezer", The Aerial Eye, Vol. 3/2, pp. 6-7

Celikoyan, T.M., Altan, M.O., Toz, G., 2003," Evaluation of a Theatre by using Low-Altitude Aerial and Terrestrial Photogrammetry", In: ISPRS Archives Vol. XXXIV-5/C15, CIPA, Antalya, Turkey, pp. 375-379.

Demir, N., Bayram, B., Alkış, Z., Helvacı, C., Çetin, I., Vögtl, T., Ringle, K., Steınle, E., 2004, “Laser

Scanning for Terrestrial Photogrammetry, Alternative System or Combined with Traditional System", ISPRS xx. Symposium, Com. V., WG V/2, İstanbul, 12-23 July 2004.

Chiabrando, F., Nex F., Piatti D., Rinaudo F., 2011, "UAV and RPV Systems for Photogrammetric Surveys in Archaelogical Areas:two Tests in The Piedmont Region (Italy)", Journal of Archaeological Science, Vol. 38(3), pp. 697-710.

Eisenbeiss, H., 2009, UAV Photogrammetry, Thesis Diss. ETH No. 18515, Technische Wissenschaften ETH Zurich, IGP Mitteilung N. 105

Everaerts, J., 2008,"The Use of Unmanned Aerial Vehicles (UAVS) for Remote Sensing and Mapping", In: ISPRS Archives Vol. XXXVII. ISPRS Congress, Beijing, China, pp.1187-1192.

Fotinopoulos, V., 2004,"Balloon Photogrammetry for Archaeological Surveys", In:ISPRS Archives Vol. XXXV-B5, XX ISPRS Congress, Istanbul, Turkey, pp.504-507.

Gesafidis, S., Kambourakis, A., Karras, G.E., Lymperopoulos, E., Madani, M., Mavrelis, G., Mavromati, D., 1999, "Digital Orthophotography in Archaeology with Low-altitude Non-metric Images", In: ISPRS Archives Vol. XXXII, Part 5/W11, pp. 8-11.

Hart, C.,1982, Kites: An Historical Survey, (2nd ed.,. Appel Publ., Mt. Verno

James, S. Aber and Susan W. Aber, 2002,"Unmanned Small-Format Aerial Photography from Kittes for Acquiring Large-Scale, High-Resolution, Multiview-Angle Imagery", ISPRS, International Archives of Photogrammetry Remote Sensing and Spatial Information Sciences, Vol. 34(1), pp. $1-6$

Leloglu, UM., Tunali, E., Algun, O., 2003, "Aerial Photos", http://vega.bilten.metu.edu.tr/aerialphoto/, accessed on 12 June, 2003.

Smith, Mike J., Chandler, J., Rose, J., 2009, "High Spatial Resolution Data Acquisition for The Geosciences: Kite Aerial Photography", Earth Surface Processes and Landforms, Vol. 34(1), pp. 155-161. Copyright $@ 2008$ John Wiley \& Sons, Ltd.

Suveg, I., Vosselman, G., 2000," 3D Reconstruction of Building Models ,Technical University of Delft, The Netherlands Photogrammetry and Remote Sensing", IAPRS, Vol. XXXIII, Amsterdam.

Ulvi, A.,Yakar, M.,2010, "An Experimental Study on Preparing Photogrammetric Rolove Plans of Antique Theatres", International Journal of the Physical Sciences, Vol. 5(7), pp. 1086-1092, July 2010, Available online at http://www.academicjournals.org/IJPS ISSN 1992 - 1950 @2010 Academic Journals

Warner, W.S., 1996, "Kiteography", The Aerial Eye, Vol. 2(2), pp. 16-17,19.

URL1:http://asiaminor.ehw.gr/Forms/fLemmaBodyExtended.aspx?lemmaID=8776, 21 Şubat 2017 